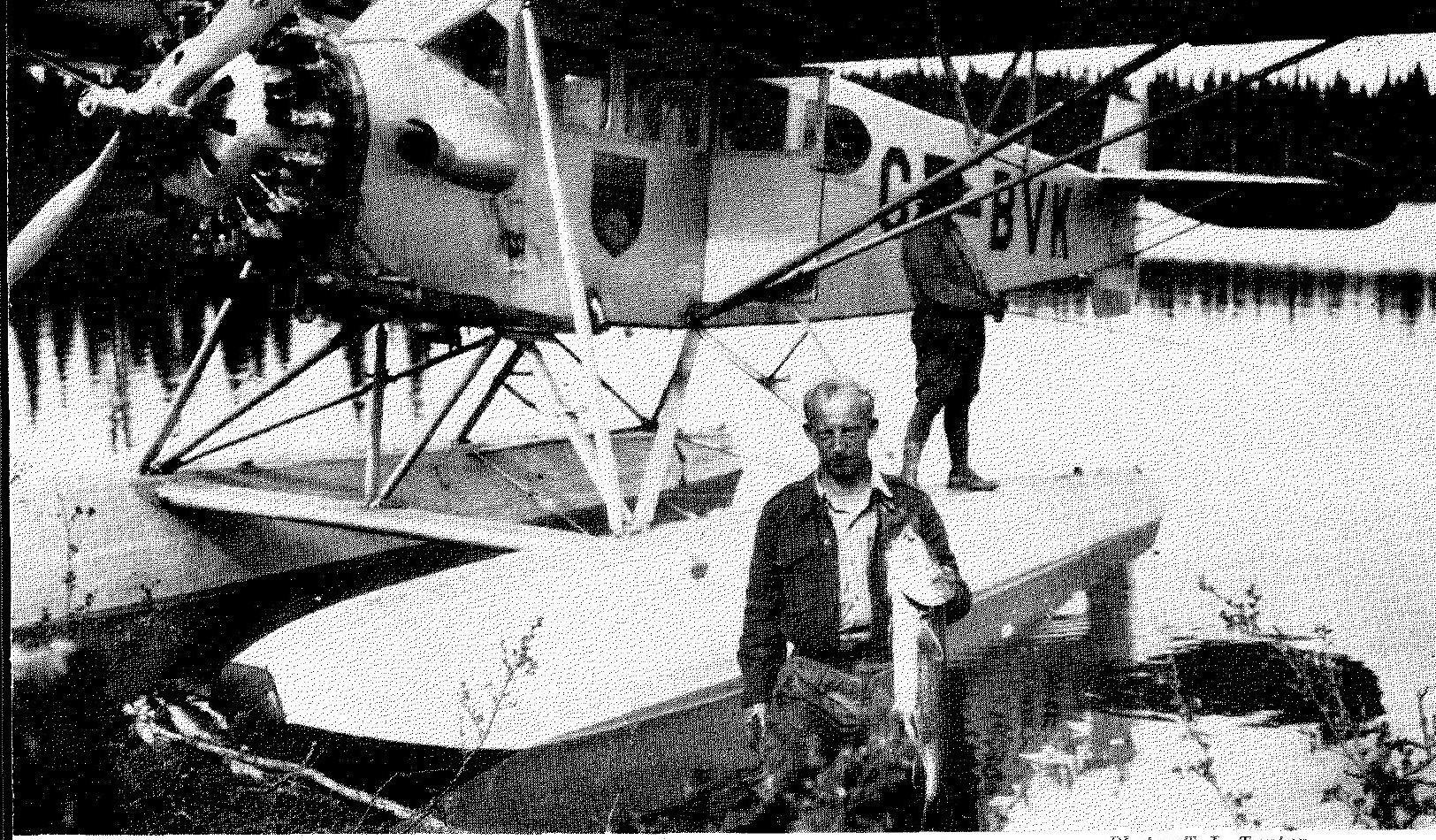

Fishing in Wishart Lake: in foreground $12 \mathrm{lb}$. lake trout.

\title{
NOTES ON FISH OF THE INTERIOR OF THE LABRADOR PENINSULA
}

\section{By Eugene G. Munroe}

A

visiron to the interior of the Labrador Peninsula familiar only with the fauna of our depleted southern waters cannot fail to be impressed by the enormous abundance of food and game fish. The writer, under the auspices of the Defence Research Board of Canada, was able to spend about six weeks in biological work during the summer of 1948 , in the Knob Lake region, situated at approximately $55^{\circ} \mathrm{N}$., $67^{\circ} \mathrm{W}$, on the Quebec-Labrador boundary. While the main objectives of the trip were not ichthyological, it was possible to make some observations on the fishes of the region. Notes on the various species will be given, followed by a brief discussion of the general features of the lakes and streams and economic considerations.

Detailed acknowledgment has been made elsewhere of the assistance from several quarters without which the expedition would have been impossible or scientifically unprofitable. The writer would like to repeat at this time, however, his indebtedness not only to the Defence Research Board for financial and other support, and to the Division of Entomology, Science Service, Department of Agriculture, for supplying technical equipment and advice, but also to the Labrador Mining and Exploration Company for providing accommodation, transport facilities, and general 


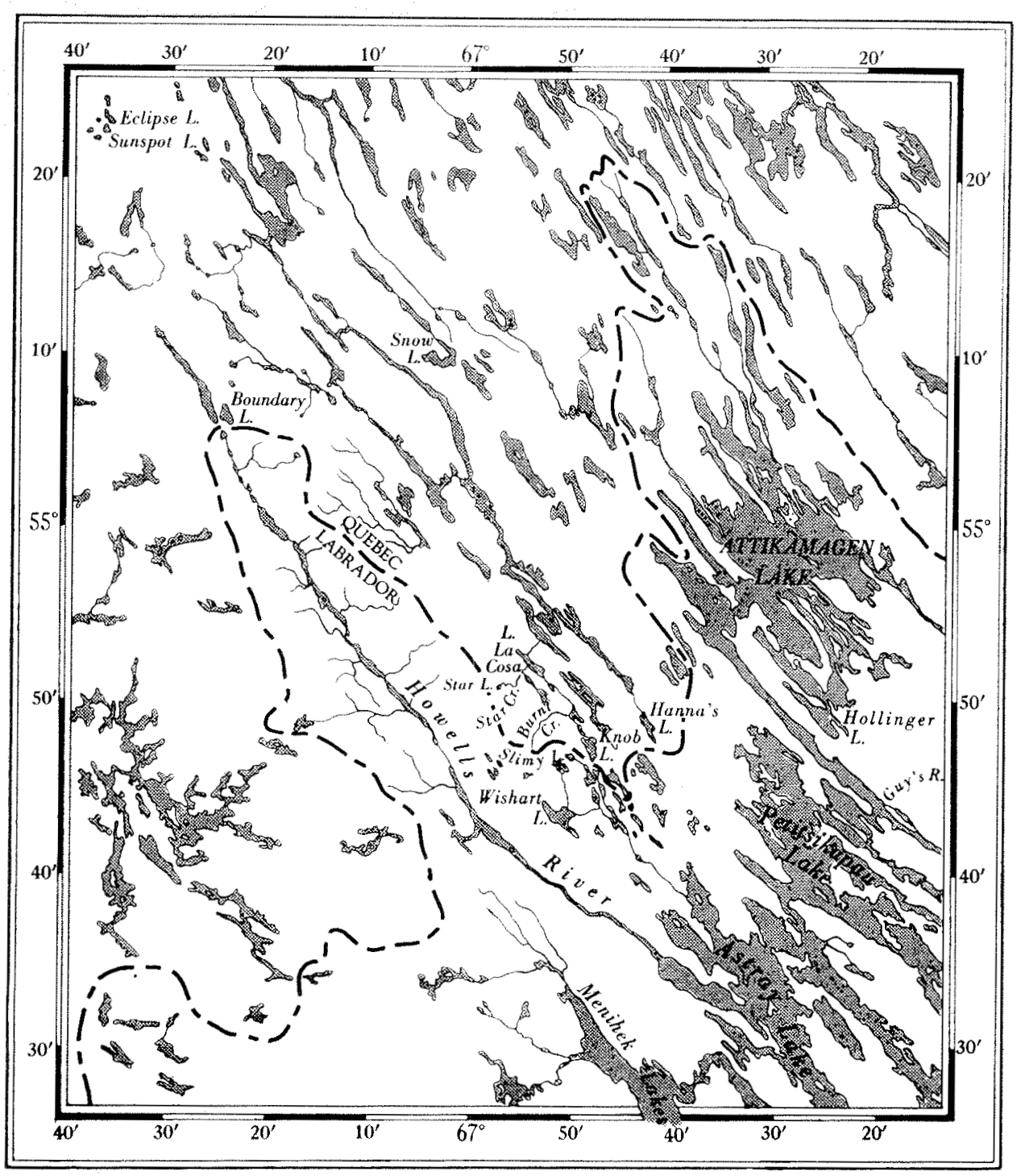

Knob Lake district.

assistance at their base at Burnt Creek. The personnel of this Company were uniformly helpful and informative. Their knowledge of biological conditions was extensive and proved as far as it could be checked to be unusually accurate; the information which they supplied was consequently of the greatest value in guiding and supplementing the writer's observations.

\section{Notes on the Species}

\section{Speckled trout (Salvelinus fontinalis)}

This is the most abundant and the most widely distributed of the food and game fishes of the region. Speckled trout exist in very large 
numbers in almost all of the lakes and in many of the streams of the area. In a favourable spot on an average lake almost every cast will result in the hooking of at least one fish. Although the abundance of the fish is general, their size varies noticeably from lake to lake. In almost every lake there seems to be a fairly definite upper size limit, which is reached or approached by a considerable proportion of the individuals at one time. Catches of trout from a single source, therefore, tend to be remarkably uniform in size, and show some correlation with the size of the lake. There are wide departures from this rule, however, and four- or five-pound trout can be obtained in numbers from some quite small lakes. In certain minute, bog-rimmed lakes the largest fish are about 6 inches in length, and individuals from 4 inches up are sexually mature. On the other hand, in the great lowland lakes of the Hamilton drainage three- to five-pound trout are common, and a specimen weighing $11 \frac{1}{2}$ pounds is said to have been taken.

The abundance of speckled trout in the Hamilton drainage on the Labrador side of the boundary appears to be about the same as in the northern Koksoak drainage in Quebec. Conditions are very similar in these two drainages, and trout-bearing lakes in the two systems are often separated by only a few hundred yards of land. In addition to the difference in size of fish from different lakes, there is also considerable colour variation, and it is likely that this is to some extent correlated with drainage system. Trout from the Hamilton drainage seemed on the average to be more heavily pigmented and to have a more extensive red breeding flush than those from the northern drainage, which were paler and more silvery, approaching the common form of the southern Laurentians. Material was not seen from a sufficient variety of localities, however, to establish this. The spawning time in this region is reported to be after the middle of October, immediately before the freezing over of the lakes.

The speckled trout examined were heavily parasitized, the gut and body cavity containing very large numbers of tapeworms and roundworms. The fish however were mostly fat and in good condition and the flesh appeared to be quite sound; most or all of the worms being removed in the normal process of cleaning.

A representative collection of worms was made, and is being studied by the writer's colleague at the Institute of Parasitology, Macdonald College, Dr. L. P. E. Choquette. Dr. Choquette's preliminary examination indicates that the worms were mainly of the following four types:

$\begin{array}{lll}\text { Cestoda } & \begin{array}{l}\text { Proteocepbalus sp. } \\ \text { Eubotbrium sp. }\end{array} & \text { adults } \\ & \text { plerocercoid larvae } \\ \text { Nematoda } & \text { Pbilonema sp. } & \text { adults } \\ \text { Acanthocephala } & \text { Echinorbyncbus sp. } & \text { adults }\end{array}$




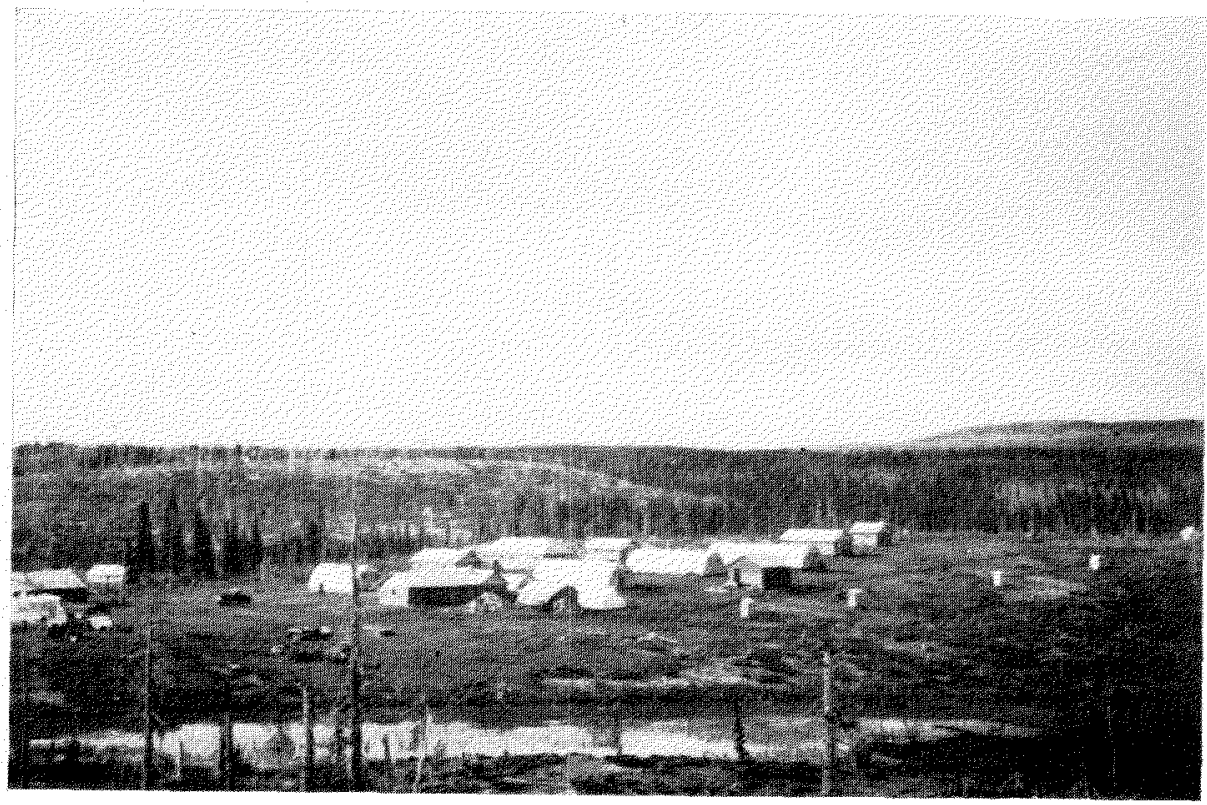

Plente: T. L. Tanton

Burnt Creek Settlement, looking southwest.

The distribution of speckled trout is general except in certain minor upland waters, such as the upper Burnt Creek system, which are barred to them by waterfalls. Specific records were obtained from the following localities:

Hamilton drainage: Wishart Lake ${ }^{1}$ Northern drainage: Hanna's Lake Slimy Lake Guy's River

Knob Lake

Star Lake

Star Creek

Lac La Cosa

(Key Lake)

Snow Lake

Eclipse Lake

No Quebec red trout (Salvelinus marstoni) or Arctic char (S. alpinus) were seen or reliably reported.

Lake trout (Cristivomer namaycush)

Like the speckled trout, the lake trout is widely distributed and abundant. It is restricted to the larger lakes, roughly speaking those more than a mile in length, so that the actual number of localities where it occurs is considerably smaller. It makes up in abundance for its restricted distribution: a party of three or four men can count on taking

${ }^{1}$ Many of the place-names given in this paper are those used by the mining companies and have not been officially adopted by the Board on Geographical Names. 
enough lake trout in a day to provide four meals for 120 mining personnel. The average weight of the fish captured is between five and ten pounds, but individuals up to 30 pounds have been reported. The mean size is thus somewhat smaller than in parts of western Canada. The total weight produced by each lake must, however, be enormous, and it is interesting that these numbers of lake trout can exist with equally massive populations of speckled trout, apparently without serious detriment to either species.

The lake trout are said to spawn in this region in about the first half of September. A single specimen collected for examination proved to be free of visceral or external parasites.

The following specific locality records were obtained:

Hamilton drainage: Wishart Lake Northern drainage: Boundary Lake Guy's River

Sunspot Lake

Hanna's Lake

Ouananiche or land-locked salmon (Salmo salar ouananiche or a similar subspecies)

The distribution of this fish appears to be much more extensive than has usually been realized. A specimen was seen from Guy's River, and Dr. J. A. Retty, of the Hollinger North Shore Exploration Company, states that he has seen it from the Menihek Lakes, also on the Hamilton drainage, and from unspecified waters on the Northern Drainage, well north of the height of land. It is quite possible that more than one colonization from the sea is represented, and without further investigation it would be rash to say that the populations from these various localities are subspecifically identical, either with one another or with the true ouananiche of Lake St. John.

Although they are widely distributed, land-locked salmon appear to be rare in this region. They are superb game fish: the Guy's River specimen, which weighed perhaps a pound and a half, was said to have outfought several three- or four-pound speckled trout taken on the same day. No data are available on the spawning of this form. The single specimen examined was free of internal or external parasites.

Whitefish (Coregonus sp.)

Whitefish have been taken in Knob Lake, and are doubtless well distributed in the larger lakes. They are not caught frequently, but this may be the result of unsuitable angling methods rather than actual scarcity. They are said to rise to the hook and line only at spawning time, which is around October 15. No specimens were seen.

Pike (Esox ?lucius)

Pike are said to occur in several of the larger lakes in the immediate vicinity of Knob Lake. No specimens were seen, but the fish reported 


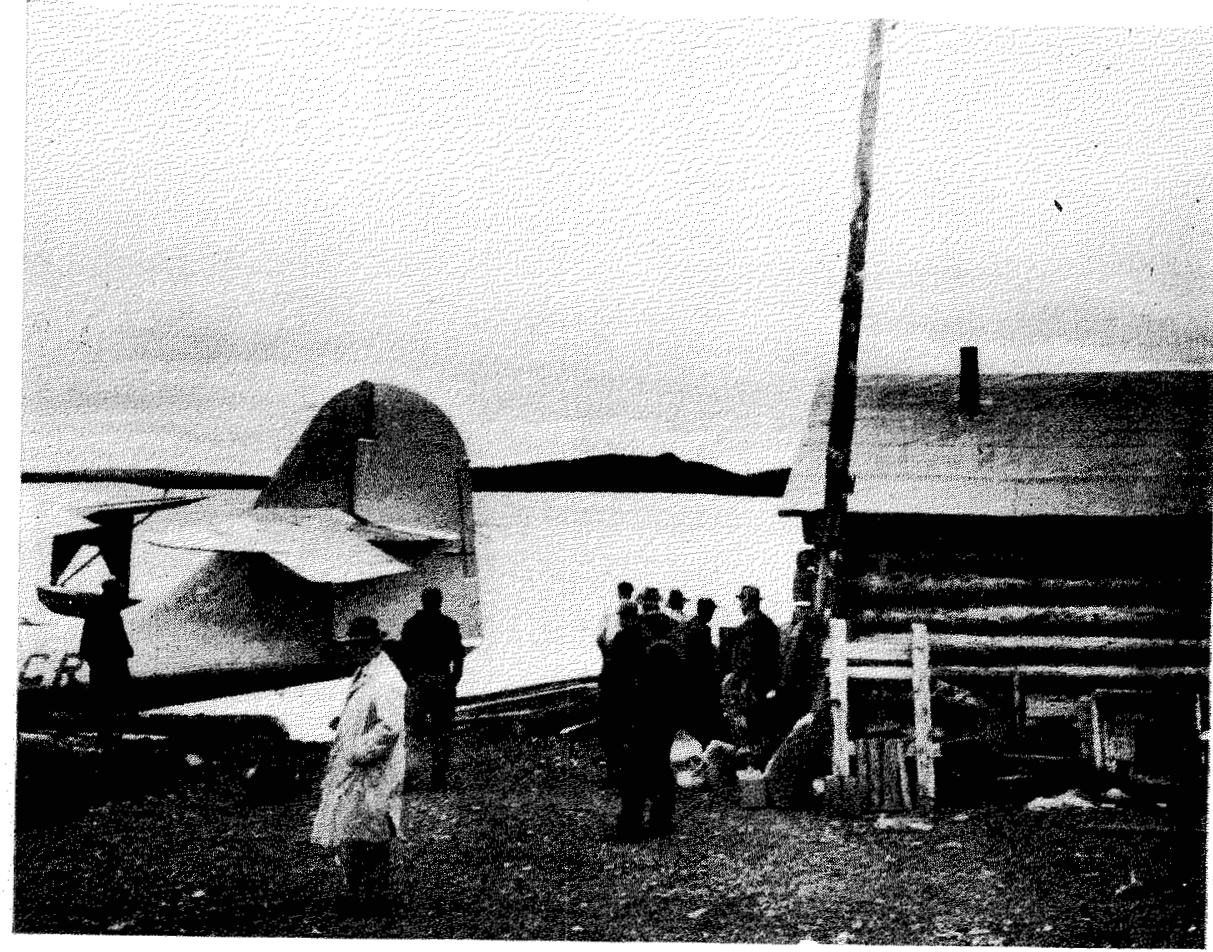

Photo:T.L. Tonton

Knob Lake, looking south. The knob south of the lake can be seen on the skyline.

is certainly an Esox and most probably the great northern pike, E. lucius. No weights or spawning data are available. Specific locality records are:

Northern drainage: Hanna's Lake Lac La Cosa (Key Lake)

Suckers and minnows (Catostomidae and Cyprinidae)

These fish, called indiscriminately "suckers" in local parlance, are extremely numerous in the Knob Lake area, but since they have little game value and are not used for food it is hard to get accurate information about them. At least four forms are said to be present, but it is possible that the differences are in part owing to age or sex. General descriptions of two of these forms were obtained:

(1) "Common sucker" (possibly Catostomus commersonii). Described as being rather pale above and silvery below, with large scales and a "sucker mouth". Spawns in streams about June 15. Recorded from Hanna's Lake.

(2) "Sturgeon sucker" (evidently not Catostomus catostomus, and probably a Cyprinid). Described as being very dark above, with small scales and a blood red dorso-lateral stripe. The head is elongate and 
"sturgeon-like" and the mouth resembles that of a whitefish. Large numbers of this species swim upstream in Knob Creek at spawning time, which is also about the middle of June.

\section{General Features of the Lakes and Streams}

An outstanding feature of this region is the number and variety of its aquatic habitats. About twenty per cent of the area of the Dyke Lake sheet of the 8 mile to the 1 inch map is shown as water, and many of the smaller bodies of water are not mapped. There is every transition from small temporary ponds to lakes larger than Lake St. John; similarly, streams range in size from small seepage- or snow-fed rivulets up to large, rapid rivers such as Howells River.

The lakes are for the most part shallow and linear in structure. The proportion of shoreline and of shallow water is unusually high, which contributes to the great biological productivity. The water is in general greenish in colour and some of the lakes are surprisingly clear.

The composition of the aquatic macrofauna suggests that insects form a very large part of the basic food supply of the fish population. In lakes the most numerous insects are the larvae of caddis flies (Trichoptera) and of midges (Chironomidae, etc.), and both larvae and adults of water beetles of various families. In the more rapid streams the larvae of Blepharoceridae and of blackflies (Simuliidae) and the nymphs of stone flies (Plecoptera) are also abundant. Mayflies (Ephemerida) and dragon flies (Odonata), important sources of fish food in more southern waters, occur only in small numbers in the Knob Lake district.

Generally speaking, lakes much under half a mile in length do not contain any significant quantity of fish, other than small speckled trout. Lakes from one half to two miles in length produce large numbers of speckled trout, and in some cases large individual fish. In lakes approaching two miles in length, numbers of lake trout and some whitefish and pike may be found, in addition to the speckled trout. The land-locked salmon has so far been recorded only from very large lakes and their tributary streams.

The small streams may contain considerable numbers of speckled trout in summer, but they are almost or quite frozen in the winter, and must apparently be restocked each year by the migration of fish from connecting lakes. The larger rivers such as Howells River may have a permanent fish fauna, but no information as to its composition is available.

The open season for most lakes is short, the ice breaking up in June 
and re-forming in October. In view of this the very large weight of fish maintained is remarkable.

\section{Economic Considerations}

The economic potentialities of such an enormous reservoir of food and game fishes are obvious. From the standpoint of the angler, the main difficulty is perhaps the superabundance of trout. The discriminating fisherman will soon tire of a pool where almost every cast brings out one or two sizable fish, regardless of the type of lure used. However, speckled trout of four pounds or more, such as are regularly taken in some localities, are not to be treated with contempt, while the land-locked salmon, when its distribution becomes better known, will add enormously to the sporting potentialities of the region.

Economically there is a very large supply of fish in this area which is quite suitable for food, and a large part of which is in the delicacy class. Thus, for instance, from Star Lake, a roughly circular lake about half a mile in diameter, situated not far from Burnt Creek, an estimatedd 100 speckled trout a week have been withdrawn during the ice-free season for the three years from 1946 to 1948, without any apparent decrease in the numbers or the average weight of the fish. The annual withdrawal may be estimated conservatively at 800 pounds. This lake is fished because of proximity to the mining camps rather than because of abundance of fish, and a much greater weight of fish can be taken with the same expenditure of time in the larger lakes where lake trout are also present. When it is considered that there are approximately 4500 square miles of water in the area of the Dyke Lake sheet of the 8 mile to the 1 inch map alone, the enormous fish populations that exist in this area can be appreciated.

It seems possible that such large supplies of fish could be utilized on a commercial basis. Even if the actual annual productivity of fish is less than the very dense natural populations might suggest, there is so much productive water area, divided among so many small lakes and streams, that a rotation of fishing grounds could easily be arranged, which would keep inroads on the fish population of any one area within safe limits. Obviously certain problems would have to be solved before the establishment of a commercial fishery would be justified. Among these are:

(1) Estimation of the actual annual productivity of waters of repre- sentative types. A reliable estimate can be obtained only by means of a fully equipped and intensive limnological survey. Such a survey should investigate not only the actual weight of lake trout, speckled trout, and other fish produced per year, but also the physico-chemical and biotic factors responsible for productivity. 
(2) Potential markets. The Knob Lake area is far removed from large centres of population; however distance is becoming a lesser obstacle with modern developments in transportation. The flying time from Knob Lake to Montreal by commercial aircraft is about four hours, and that from areas closer to the St. Lawrence is correspondingly shorter. A charter has in fact been obtained by the mining companies from the Dominion Government for building a railway from Seven Islands to the Knob Lake area. The projected mining developments in the region are certain to provide a local market for at least a moderate weight of fish. Experience at Great Slave Lake² suggests that remoteness from centres of population is not in itself an insuperable barrier to the establishment of a fishery.

(3) Conservation and allied problems. Aside from problems of conservation which affect the permanence of the fishery itself, other questions might have to be considered, particularly if the commercialization of speckled trout should seem justified. The laws which now govern the catching and disposal of speckled trout are based principally on the precarious situation of that fish in southern waters, and any recommendation for the modification of these laws to permit the marketing of speckled trout from northern sources would have to include very careful provision, not only for the conservation of the northern populations, but also for the prevention of any adverse reaction on conservation in the south. The possible effect of the depletion of fish populations on the livelihood of Indians in the northern area is another subject which would need careful study.

Commercial fishing in this area should clearly be approached with caution and after due preliminary study. In contrast, the problem of conservation is one which should be faced immediately. The growing population of this area and the development of mining and hydroelectric operations are certain to have an adverse effect upon fish resources over a wide area, unless conservation measures are adequate and prompt. It is to be hoped that these waters will not be ruined, as so many natural resources have been in the past.

${ }^{2}$ Rawson, D. S. "Greát Slave Lake", in 'North-west Canadian fisheries surveys in 1944 45'. Fisheries Research Board of Canada. Bulletin No. 72, Ottawa 1947, pp. 45-68. 